\title{
PERSIAN WIND TOWERS: ARCHITECTURE, COOLING PERFORMANCE AND SEISMIC BEHAVIOUR
}

\author{
B. HEJAZI ${ }^{1} \&$ M. HEJAZI ${ }^{2}$ \\ ${ }^{1}$ Islamic Azad University, Khorasgan (Isfahan) Branch, Department of Architecture, Isfahan, Iran. \\ ${ }^{2}$ University of Isfahan, Faculty of Engineering, Department of Civil Engineering, Isfahan, Iran.
}

\begin{abstract}
Persian wind towers, badgirs, are passive building cooling systems that use nature to provide comfort to people in hot-dry regions. They catch fresh air and channel it down to cool the internal spaces. Sometimes they perform as ventilators and conduct the pleasant air from the courtyard on the ground floor up to the top of the wind tower.

In this paper, construction technology, typology based on location and number of intakes, cooling performance, and seismic behaviour of badgirs are described. Wind towers in Kashan, Central Iran, are studied for their cooling functioning and structural behaviour against earthquakes. Four different heights for the wind towers are considered. The effects of wind tower height, wind orientation and wind velocity on mass flow and temperature in wind towers are presented.
\end{abstract}

Keywords: Badgir, cooling performance, earthquake, mass flow, passive system, Persian wind towers, temperature, typology.

\section{INTRODUCTION}

Wind tower, badgir, is an essential architectural element in hot-dry areas of Iran, in particular central parts such as Kashan, Yazd and Kirman, and southern part of the country, i.e. the northern coastlines of Persian Gulf. Badgir as a traditional ventilation and cooling system has been used for many centuries in different countries in the Middle East and northern Africa [1].

Architectural features and cooling performance of Persian wind towers have been the focus of a number of researchers during last decades. Excavations of Masouda in Shahrud, Northern Iran, prove the existence of badgir in Iran in 4000 BC [2]. Hejazi [3] and Hejazi and Mehdizadeh Saradj [4-7] described climatic adaptability in Persian vernacular architecture and cooling performance of Persian badgirs. A number of doctoral and master's theses have been dedicated to Persian badgirs. Roaf [8] worked on the wind towers of Yazd in 1988. Memari [9] compared two new types of wind towers in 1991. Mahyari [10] and Ghiabaklou [11] studied wind towers and passive evaporative cooling systems in 1996. Dehqani [12] tested the performance of two new types of wind towers and compared with conventional ones in 2001. In 2002, Mousavidavar [13] tested and analysed the performance of wind towers for cooling systems of buildings. Arjanan Mirjani [14] studied the badgirs of Yazd in 2004. Mahmoudi [15] studied the architecture of wind towers and the effect of type of wind towers on thermal behaviour in 2006.

The most comprehensive work on natural air conditioning and cooling in Persian traditional buildings belongs to Bahadori and Yaghoubi [16], in which different aspects of passive systems including analysis and design formulae for different types of passive building cooling systems such as wind towers, domical roofs, basements and cellars, courtyards and cisterns are dealt with. The relation between wind towers performance and air temperature and wind velocity was studied by Bahadori [17-19]. The performance of a wind tower as a ventilator by using fresh air of the courtyard and basement in traditional houses for cooling was described by Bahadori and Yaghoubi [16] and Yaghoubi et al. [20]. Badran Ali [21] and Nouanegue et al. [22] performed experimental and numerical research into cooling systems of wind towers. Two improved designs of wind towers, one with wetted curtains hung inside the wind tower and the other one with wetted surfaces, were tested 
by Bahadori et al. [23]. A computer code for numerical simulation of natural evaporative cooling performance of wind towers was developed by Kalantar [24]. Mahmoudi et al. [25-27] studied the effect of cross-sectional shape of a badgir on its cooling performance and described its cooling system. Azami [28] explained different types of wind towers and its architectural elements. Dehnavi et al. [29] studied the effect of dimensional parameters of wind towers with a square plan on their cooling performance. Hejazi and Hejazi [30] studied the effect of height, orientation and velocity of wind on passive cooling system of wind towers.

\section{CONSTRUCTION TECHNOLOGY}

A wind tower is made of adobe or brick. It is a canal that conducts wind from the top to the bottom. Construction of a wind tower consists of three phases. In the first phase, the lower part is constructed from the basement of the building up to the roof level (Fig. 1a). There are two openings, one in the basement at floor level in order to make the air wet and cool and another in the living room at floor level or one-third to one-fourth of room height (Fig. 1c).

In the second phase, the upper part of the badgir is built on the roof. For this reason, two different methods may be used. In the first method, four adobe or brick walls are constructed on the roof and stiffened with a wooden ring beam at the top (Fig. 1a). In the second method, four wooden round vertical columns are placed at four corners (Fig. 1b). Horizontal and inclined wooden elements are added to stiffen the wooden frame. Adobe or brick units with mortar are placed to make the four walls of the badgir. A pair of horizontal crossed wooden beams is placed at the top, on which vertical wooden or masonry vertical crossed partitions are built (Fig. 1b and d).

In the third phase, the badgir is roofed with wooden boards and mud-straw mix, and a rain leader is inserted to conduct rainwater.

\section{TYPOLOGY BASED ON LOCATION}

A vast part of Iran is desert (Fig. 2). Different types of wind towers are constructed in different parts of the country in order to deal with regional climatic conditions. Wind towers may be categorised from different viewpoints, such as location, number of intakes, shape of plan, and view. Sometimes, they take their names from the city in which they are built.

\subsection{Ardakani wind tower}

This type of wind tower is used in the city of Ardakan, east of Isfahan and near Yazd (Fig. 2). It is one-sided; i.e. it has only one intake, which is towards Isfahan (west) with fresh wind and the other three sides are closed to sandy winds of the desert. The Ardakani badgir is simple and economic; hence, a wind tower can be used for each room in a house.

\subsection{Kirmani wind tower}

Kirmani badgir is used in Kirman (Fig. 2). It is simple and used by low-income working families. It is made of adobe and two-sided; i.e. it has two intakes towards appropriate wind directions. Its function is more efficient than Ardakani wind tower. This type of badgir is also used for cisterns.

\subsection{Yazdi wind tower}

Yazd, Central Iran (Fig. 2), is known with its numerous badgirs. There are more than 180 wind towers that dominate the city. Yazdi wind tower is used by upper class families in Yazd, although some 


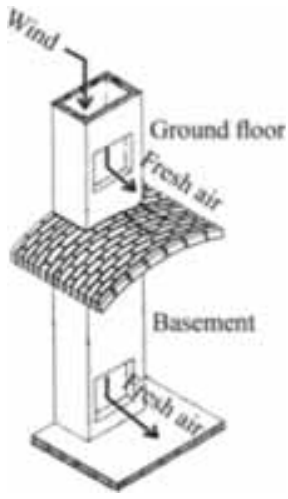

(a)

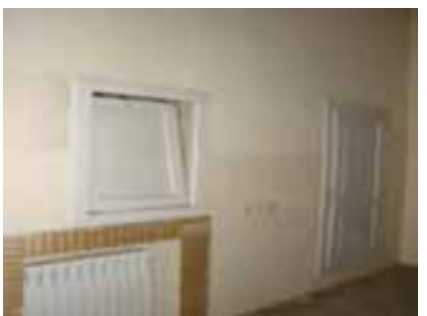

(c)

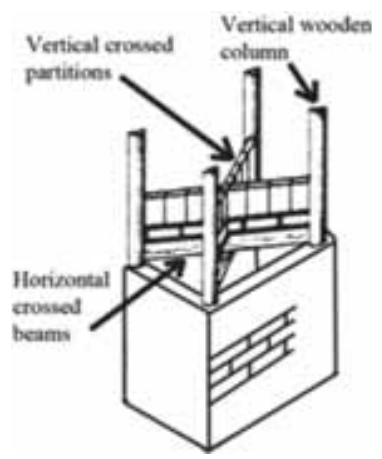

(b)

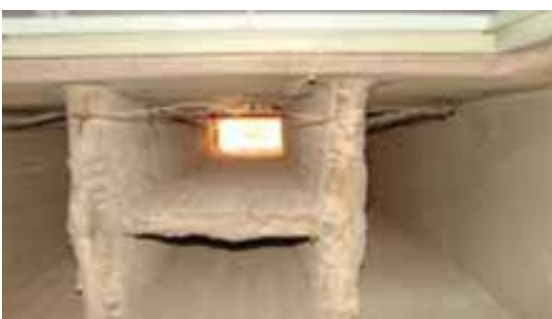

(d)

Figure 1: Construction technology of a wind tower: (a) intake canal (after Zomarshidi [31]), (b) structural elements (after Zomarshidi [31]), (c) opening in the living room and (d) vertical partitions inside intake canal.

are also used in nearby villages. It is larger, taller and more sophisticated than other types of wind towers. It is usually four-sided; i.e. it has four intakes oriented appropriately, as Yazd is located between two mountains that prevent entering sandy winds of the desert.

\section{TYPOLOGY BASED ON NUMBER OF INTAKES}

Wind towers can be categorised according to the number of intakes.

\subsection{One-sided wind towers}

A one-sided badgir has only one intake, which is oriented towards clean wind (Fig. 3). Other sides are closed in order to prevent entering sandy airflow. One-sided wind towers are generally constructed near or in the deserts, such as in Ardakan, Maybod, Mahan and Bam (Fig. 2). It is sometimes called Ardakani badgir.

\subsection{Two-sided wind towers}

In a two-sided badgir, sometimes known as Kirmani badgir, the main intake canal is divided into two parts by using a vertical partition; hence, the two intakes are at opposite sides (Fig. 4). 


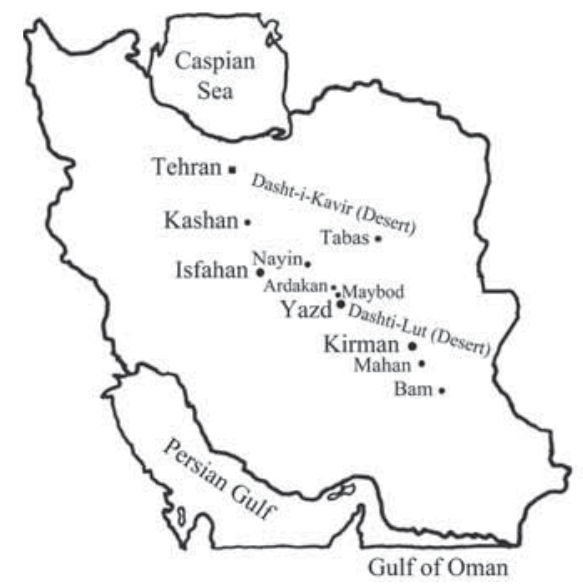

Figure 2: The map of Iran.

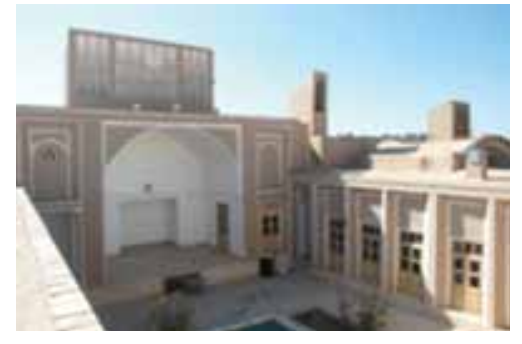

(a)

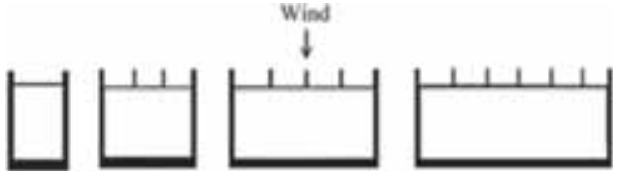

(b)

Figure 3: One-sided (Ardakani) badgir: (a) a house in Ardakan and (b) typical plans.

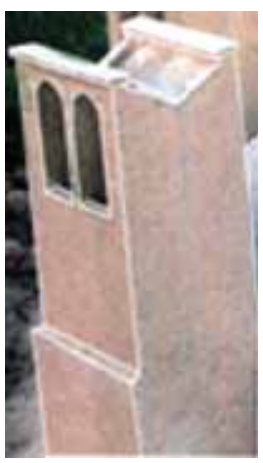

(a)
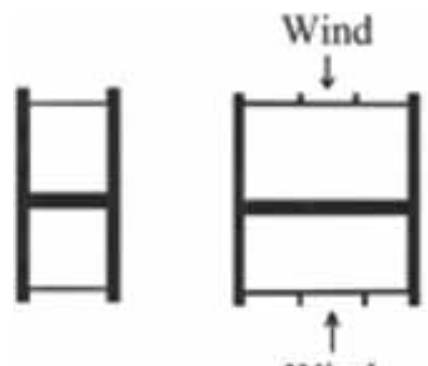

Wind

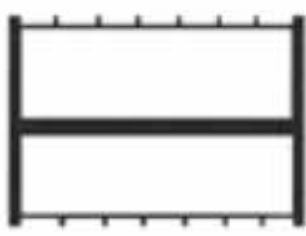

(b)

Figure 4: Two-sided (Kirmani) badgir: (a) cistern of Dawlat-Abad garden, Yazd and (b) typical plans. 


\subsection{Three-sided wind towers}

Three-sided wind towers are rarely built; an example is the badgir in Tabas (Figs 2 and 5).

\subsection{Four-sided wind towers}

This is the most popular type of wind tower, also called Yazdi badgir. Two-vertical intersected partitions divide the main intake canal into four sections (Fig. 6).

\subsection{Six- and eight-sided wind towers}

These types of wind towers can intake fresh air from different directions. They are mostly used on the top of cisterns to make water cool. The Dawlat-Abad wind tower with a height of $33.8 \mathrm{~m}$ in Yazd is eight-sided (Fig. 7).

\section{COOLING PERFORMANCE OF A WIND TOWER}

Air flows through windward openings of a wind tower when wind blows towards it (Fig. 8). A part of air exits from the leeward opening of the wind tower and causes air loss. The external and internal

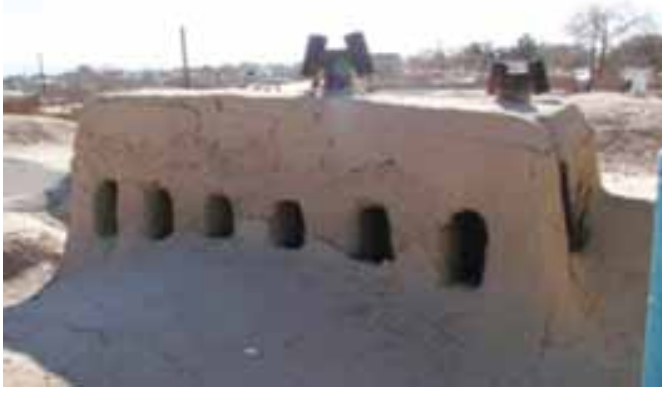

(a)

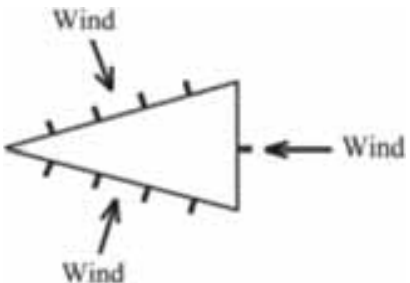

(b)

Figure 5: Three-sided badgir: (a) a house in Tabas and (b) typical plans.

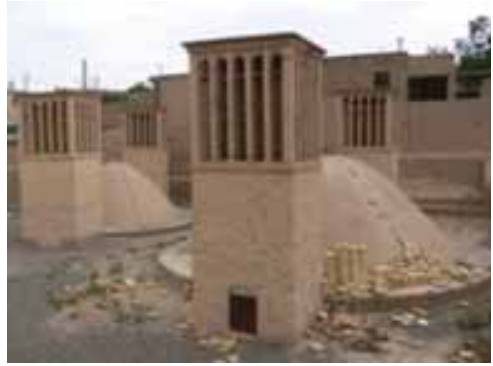

(a)

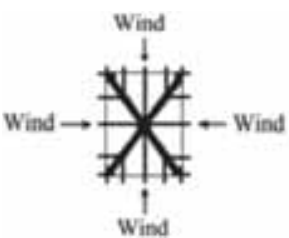

(b)

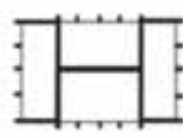

Figure 6: Four-sided (Yazdi) badgir: (a) a cistern in Nayin and (b) typical plans. 


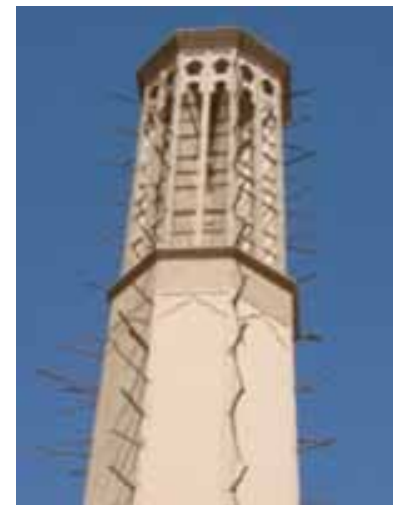

(a)

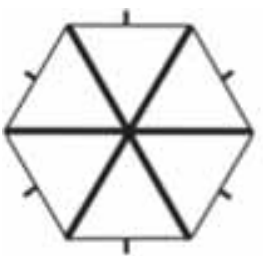

(b)

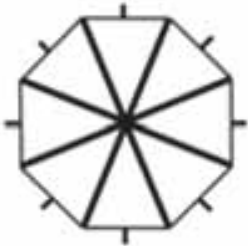

Figure 7: Six- and eight-sided badgirs: (a) Dawlat-Abad wind tower, Yazd and (b) typical plans.

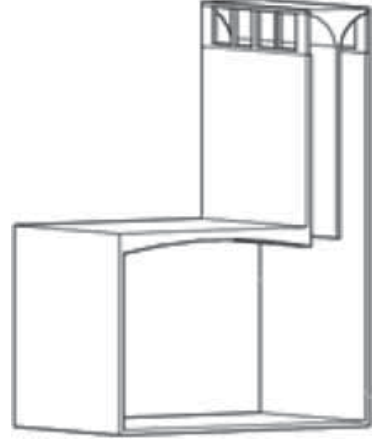

(a)

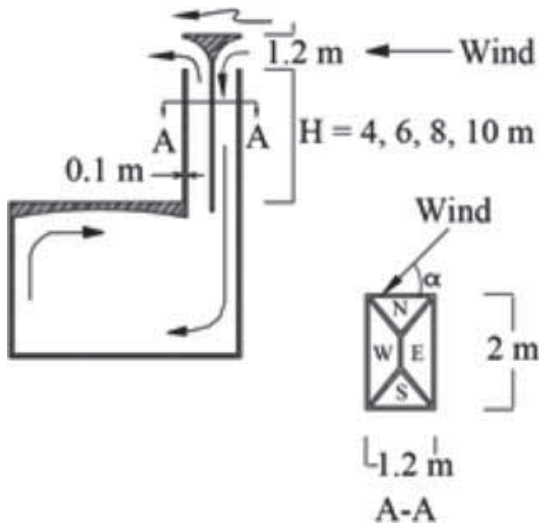

(b)

Figure 8: Wind tower, badgir: (a) isometric view and (b) vertical and horizontal cross-sections.

parts of a wind tower cool down at night, respectively, due to heat radiation of external surface of the wind tower and circulation of cool ambient air through the wind tower and building. The coolness is stored in the building mass and the stored energy provides thermal comfort on the following day. Warm air passing through the wind tower is cooled before entering the building during the day. Air passes over a moisturing surface in some buildings and causes evaporative cooling. Inside the building is cooled by the wind tower until the temperature of its surfaces becomes greater than that of ambient air due to sun radiation. The wind tower, thus, functions as a ventilator. If the air is conducted towards the basement, over wet surfaces or over qanat water running in the basement, the wind tower can continue cooling inside the building for the whole day.

In Fig. 8b, the pressure coefficients are positive for the $\mathrm{N}$ and $\mathrm{E}$ openings, and negative for the $\mathrm{S}$ and $\mathrm{W}$ openings of cross-section $\mathrm{A}-\mathrm{A}$. Thus, air enters the $\mathrm{N}$ and $\mathrm{E}$ openings. A part of air exits from the $\mathrm{S}$ and $\mathrm{W}$ openings and a part of air enters the building and then leaves the building from the $\mathrm{S}$ and $\mathrm{W}$ openings at the top of the wind tower. The amount of airflow in each path can be increased or 
decreased by decreasing or increasing the flow resistance of the path. The construction of the vertical wall (partition) inside the wind tower, which divides the vertical section of the wind tower into two parts (W and $\mathrm{E}$ ), is for increasing the flow resistance for openings with negative pressure coefficients (the $\mathrm{S}$ and $\mathrm{W}$ openings in cross-section $\mathrm{A}-\mathrm{A}$ ) in order to prevent air leaving from these openings.

\subsection{Mass flow and thermal exchange calculations}

The amount of volumetric airflow, $\bar{V}_{a b}$, passing through the wind tower is calculated using the following equation:

$$
\bar{V}_{a b}=\frac{\Delta q_{a b}}{R_{a b}}
$$

where $R_{a b}$ is the flow resistance and $\Delta q_{a b}$ is the pressure difference between the windward side and other sides according to eqn (2):

$$
\Delta q_{a b}=q_{a}-q_{b}=\frac{1}{2}\left(C_{q a}-C_{q b}\right) \rho V^{2}
$$

where $q, C_{q}, \rho$ and $V$ are the wind pressure, wind pressure coefficient, mass density of air and wind velocity. $a b$ denotes the air path from opening $a$ to opening $b$. Wind pressure can be calculated using the following equation:

$$
q=\frac{1}{2} C_{q} \rho V^{2}
$$

After determining volumetric airflow by eqn (1) for each path and assuming a constant mass density of air, it is possible to use continuity equation or the law of conservation of mass, i.e. the total entering air mass is equal to the total exiting air mass, to determine airflow at each path by using eqn (4).

$$
\sum \bar{V}_{a b}=0
$$

The temperature of the airflow in the wind tower depends on the air temperature at the entering point and the thermal exchange of air with internal surfaces of the wind tower. For the determination of thermal exchange, it is necessary to consider the thermal network of the wind tower and solve flow equation and thermal exchange equation together. For the determination of hourly air temperature, eqns (5)-(7) are used [32]. Maximum and minimum temperatures are assumed to occur at 3 O'clock in the afternoon and 3 O'clock in the morning, respectively.

$$
T-\bar{T}=\frac{1}{2} A_{t} \cos \dot{\omega}(t-15)
$$

where

$$
\begin{aligned}
& \bar{T}=\frac{1}{2}\left(T_{x}+T_{n}\right) \\
& A_{t}=\frac{1}{2}\left(T_{x}-T_{n}\right)
\end{aligned}
$$

$T, t, T_{x}$ and $T_{n}$ are hourly temperature, time (h), mean value of monthly maximum and minimum temperatures, respectively, and $\dot{\omega}=2 \pi / 24$.

Formulae for determination of solar radiation density on various surfaces are presented in References [30, 33].

In order to perform the calculations, the height of the wind tower is divided into smaller parts (of, for example, 1-m high), and flow and thermal exchange equations are written for each part to determine the velocity and temperature of the leaving air from that part. The determined velocity and 
temperature of exiting air from each part are the velocity and temperature of the entering air to the next part. Calculations are repeated until the last part, where the velocity and temperature of air exiting the wind tower and entering the building are calculated.

\subsection{Results for studied wind towers}

Figure $8 \mathrm{~b}$ shows the dimensions of the studied wind towers, which are made of brick masonry materials. The rectangular cross-section of wind towers is $1.2 \times 2 \mathrm{~m}^{2}$. The thickness of walls is $0.1 \mathrm{~m}$. Four walls are pierced, each with a rectangular shaped opening. Openings of wider walls have a width of $1.8 \mathrm{~m}$ and a height of $1.1 \mathrm{~m}$. Openings of narrower walls are $1-\mathrm{m}$ wide and 1.1-m high. Four different heights of 4, 6, 8 and $10 \mathrm{~m}$ from the roof level have been considered for the wind towers. Three different wind velocities of $0,7.5$ and $15 \mathrm{~m} / \mathrm{s}$, and three wind directions of $\alpha=0^{\circ}, 45^{\circ}$ and $90^{\circ}$ have been used in analyses. It has been assumed that wind towers are in Kashan, Central Iran, with $T_{x}=34.6^{\circ} \mathrm{C}$ and $T_{n}=16.8^{\circ} \mathrm{C}$ for July.

Obtained results indicate that the effect of the velocity and direction of wind on the temperature of air entering to the building is negligible. The minimum and maximum temperatures are about $17^{\circ} \mathrm{C}$ and $34^{\circ} \mathrm{C}$ at about $3 \mathrm{O}^{\prime}$ clock in the morning and at about $3 \mathrm{O}^{\prime}$ clock in the afternoon, respectively, on a typical summer day.

As an example, Fig. 9 shows the variation of mass flow entering the building for wind directions of $0^{\circ}, 45^{\circ}$ and $90^{\circ}$, and wind velocities of 0 and $7.5 \mathrm{~m} / \mathrm{s}$ for a wind tower with a height of $8 \mathrm{~m}$ from the roof. When the velocity of the wind is equal to $0 \mathrm{~m} / \mathrm{s}$, i.e. wind does not blow, airflow is very small. From around 4 O'clock in the morning until about 10 O'clock at night, the airflow is negative; i.e. the wind tower functions as a ventilator and the direction of air is from the bottom to the top. The reason is that from 4 O'clock in the morning, the wind tower walls get warm as a result of sun radiation and outside air is cool. During the day, the outside air temperature increases but solar radiation absorption also increases and still air flows upwards. From 10 O'clock at night until 4 O'clock next morning, sky radiation occurs and wind tower surfaces, and as a result air, become cooler and, therefore, airflow is downwards.

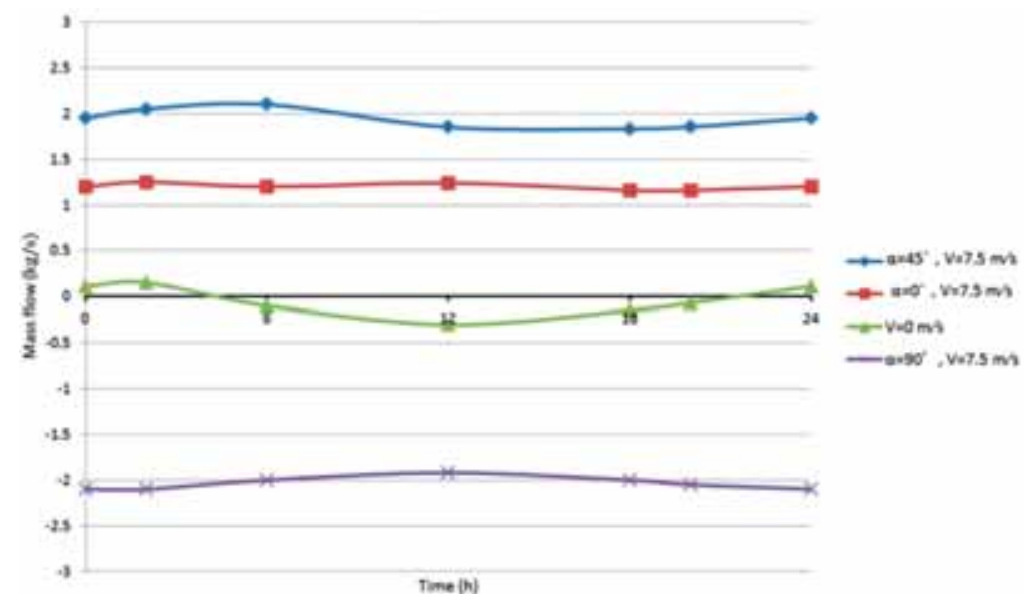

Figure 9: Variation of mass flow entering from the wind tower to the building on a typical summer day for wind velocity of 0 and $7.5 \mathrm{~m} / \mathrm{s}$ for a wind tower with a height of $8 \mathrm{~m}$. 
Wind with a larger velocity results in a greater mass flow. For wind direction of $45^{\circ}$, for example, maximum mass flows are 5.9 and $2.1 \mathrm{~kg} / \mathrm{s}$ for wind velocities of 15 and $7.5 \mathrm{~m} / \mathrm{s}$, respectively. The wind direction of $45^{\circ}$ causes more mass flow than other directions; maximum mass flows are 2.1, 1.2 and $2.1 \mathrm{~kg} / \mathrm{s}$ for wind directions of $45^{\circ}, 0^{\circ}$ and $90^{\circ}$, respectively. Mass flow for the wind direction of $90^{\circ}$, i.e. normal to the smaller dimension of the wind tower, is negative. For this case, the wind tower functions as ventilator; the air of the courtyard on the ground floor enters the building and rises up through the wind tower. This is an important issue in choosing the directions of the openings of the wind tower with respect to the dominant wind direction and the courtyard. By choosing an appropriate direction, outside warm air is prevented from entering the wind tower; instead, the cool air of the courtyard, which is designed with a garden and a small pool creating a suitable microclimate (Fig. 3a), passes through the ground spaces and rooms and then elevates in the wind tower.

Figures 10 and 11 show the variations of air temperature and mass flow entering from the wind tower to the building for different heights of the wind tower and different wind velocities and directions, respectively. Higher wind towers and winds with smaller velocities increase the temperature, but maximum temperature difference for different heights and different wind velocities and directions is only about $0.5^{\circ} \mathrm{C}$, which is negligible. Mass flow decreases for higher wind towers. For example, for wind direction of $45^{\circ}$ and wind velocity of $15 \mathrm{~m} / \mathrm{s}$, which causes the maximum mass flow, there is a decrease of $13 \%$ in mass flow when the height increases from 4 to $10 \mathrm{~m}$. A decrease in wind velocity decreases mass flow further. For wind direction of $45^{\circ}$ and height of $4 \mathrm{~m}$, which produces the maximum mass flow, there is a decrease of $65 \%$ in mass flow when wind velocity decreases from 15 to $7.5 \mathrm{~m} / \mathrm{s}$.

\section{SEISMIC BEHAVIOUR OF WIND TOWERS}

Seismic analysis has been performed to investigate the effects of earthquakes on the wind towers.

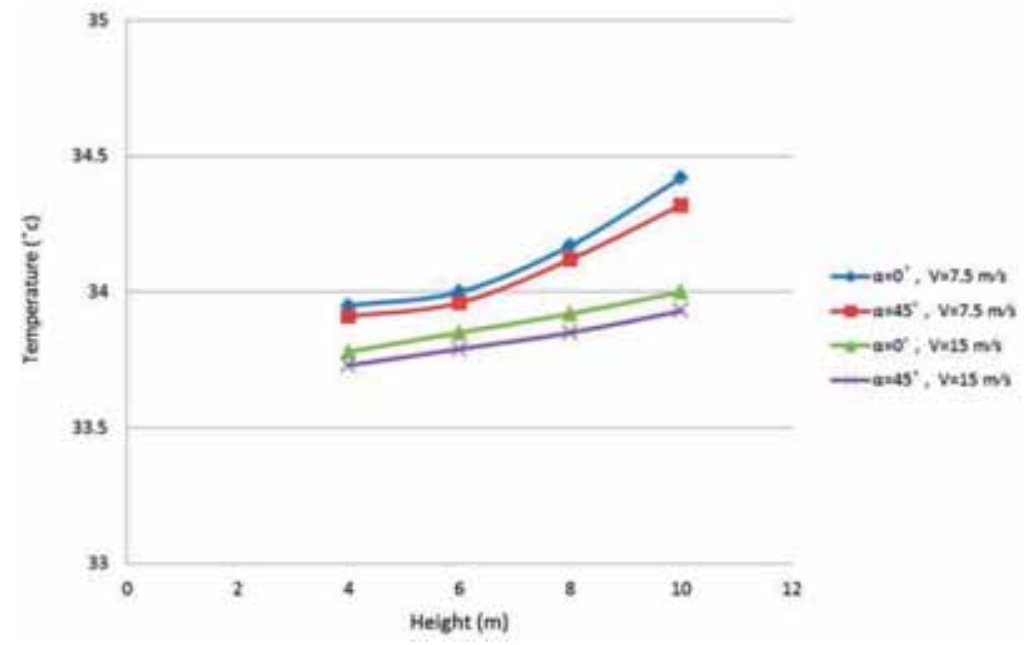

Figure 10: Variation of air temperature entering from the wind tower to the building versus wind tower height for different wind velocities and directions. 


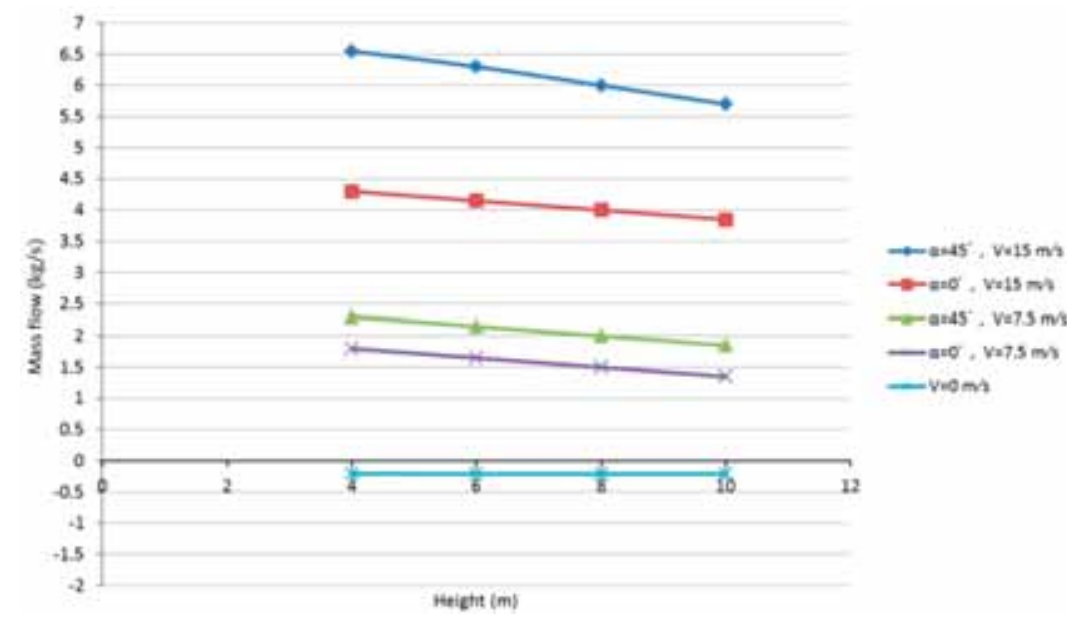

Figure 11: Variation of mass flow entering from the wind tower to the building versus wind tower height for different wind velocities and directions.

Table 1: Mechanical properties of brick masonry materials $[4,6]$.

\begin{tabular}{ll}
\hline Bulk density $\left(\mathrm{kg} / \mathrm{m}^{3}\right)$ & 1650 \\
Modulus of elasticity $(\mathrm{MPa})$ & 3700 \\
Poisson's ratio & 0.15 \\
Tensile strength $(\mathrm{MPa})$ & 0.37 \\
Compressive strength $(\mathrm{MPa})$ & 3.65 \\
\hline
\end{tabular}

\subsection{Studied wind towers}

The same wind towers, for which mass flow and thermal exchange calculations have been carried out in Section 5, have been studied for seismic behaviour. Four different heights of 4, 6, 8 and $10 \mathrm{~m}$ from the roof level have been considered (Fig. 8b).

\subsection{Analysis method}

Three-dimensional finite element method has been used for non-linear time history dynamic analysis.

\subsection{Mechanical properties of brick masonry materials}

Mechanical properties of brick masonry materials are shown in Table $1[4,6]$. A linear-parabolic behaviour has been used for stress-strain relation (Fig. 12) [34].

\subsection{Failure criterion}

Willam-Warnke failure criterion [35], which is suitable for brittle materials, has been used. 


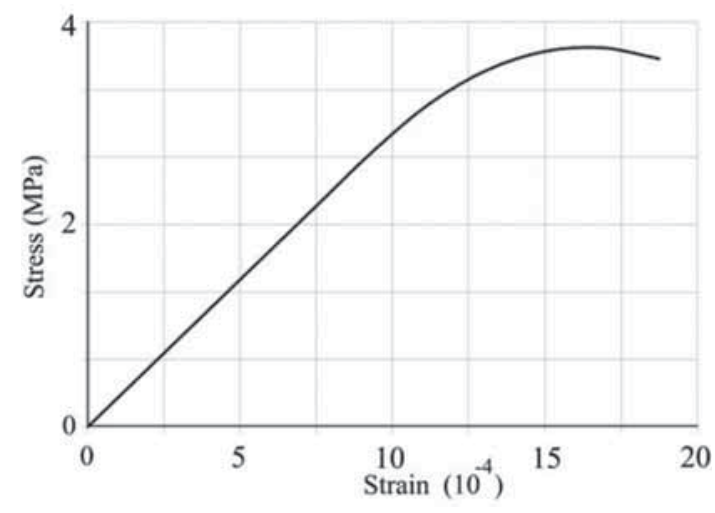

Figure 12: Stress-strain diagram of brick masonry materials.

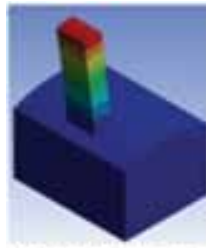

Mode shape no. 1

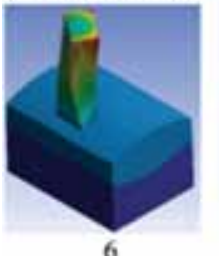

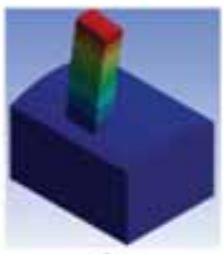

2

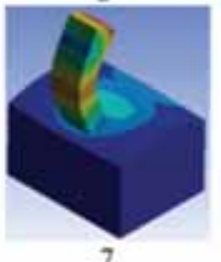

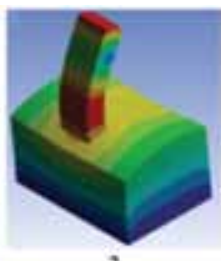

3

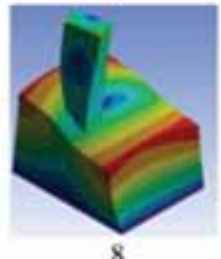

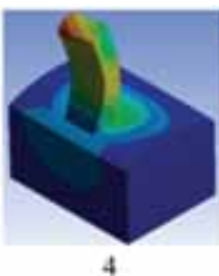

4

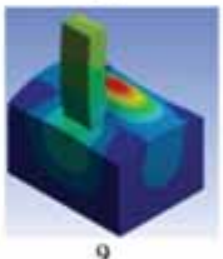

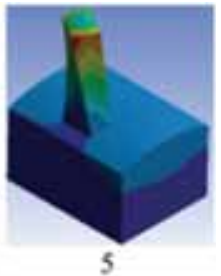

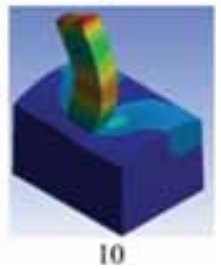

Figure 13: First 10 mode shapes of the 6-m high wind tower.

\subsection{Modal analysis}

It is assumed that the wind tower belongs to a building with a rectangular plan of $6 \times 8 \mathrm{~m}^{2}$, with walls of $1-\mathrm{m}$ thick and 5-m high. The shapes and frequencies of the first 10 modes for the 6-m high wind tower are shown in Fig. 13 and Table 2, respectively. Frequencies range from 4.89 to $43.86 \mathrm{~Hz}$.

\subsection{Non-linear time history dynamic analysis}

According to the Iranian Seismic Code [36], seven scaled ground motion records appropriate to design hazard levels of Kashan have been selected. The design value of stresses and deformations has been taken as its mean value over all ground motions. Due to the tiny cracks in masonry structures, a damping ratio of $5 \%$ has been chosen. Used records are presented in Table 3. 
Table 2: Frequencies of first 10 modes of the 6-m high wind tower.

\begin{tabular}{lc}
\hline Mode number & Frequency $(\mathrm{Hz})$ \\
\hline 1 & 4.89 \\
2 & 8.37 \\
3 & 22.62 \\
4 & 28.52 \\
5 & 28.54 \\
6 & 29.07 \\
7 & 35.98 \\
8 & 38.78 \\
9 & 42.28 \\
10 & 43.86 \\
\hline
\end{tabular}

Table 3: Characteristics of selected earthquake records.

\begin{tabular}{lccc}
\hline Earthquake & Date & Magnitude $(\mathrm{M})$ & $\begin{array}{c}\text { Maximum ground } \\
\text { acceleration }(g)\end{array}$ \\
\hline Coyote Lake & $1979 / 6 / 8$ & 5.7 & 0.248 \\
Morgan Hill & $1984 / 4 / 24$ & 6.2 & 0.212 \\
Northridge & $1994 / 1 / 17$ & 6.7 & 0.245 \\
Parkfield & $1966 / 1 / 17$ & 6.1 & 0.246 \\
San Fernando & $1971 / 9 / 2$ & 6.6 & 0.21 \\
Superstition Hills & $1987 / 11 / 24$ & 6.7 & 0.247 \\
Whittier Narrows & $1987 / 1 / 10$ & 6 & 0.243 \\
\hline
\end{tabular}

Analyses show that all wind towers fail due to earthquakes. Figure 14 and Table 4 show the stresses in the 6-m high wind tower subjected to the Northridge earthquake at 11.79 s, i.e. the time of failure. At $11.79 \mathrm{~s}$ the Willam-Warnke failure criterion is violated; induced tensile stress is $56.76 \%$ of tensile strength, compressive stress is $33.97 \%$ of compressive strength and displacement is 0.0124 $\mathrm{m}$. Taller wind towers fail earlier than lower one; hence, they are more vulnerable.

\section{CONCLUSIONS}

Construction technology, typology, cooling functioning and seismic behaviour or Persian badgirs, with focus on wind towers in Kashan, were described. The effect of height, wind orientation and velocity on mass flow and temperature in wind towers were studied. The number of intakes and orientation of badgirs are selected based on the direction of the dominant wind, location and geographical conditions. A wind tower can be one-, two-, three-, four-, six- or eight-sided. In cities near the desert, wind tower faces are closed to sandy winds in order to prevent entering dusty winds of the desert. A badgir functions as a ventilator when wind does not blow or wind direction is $90^{\circ}$, i.e. mass flow is negative and airflow is from the bottom to the top of the wind tower. For cases where 


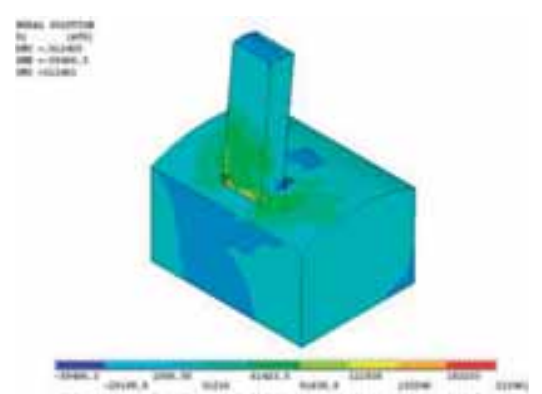

(a)

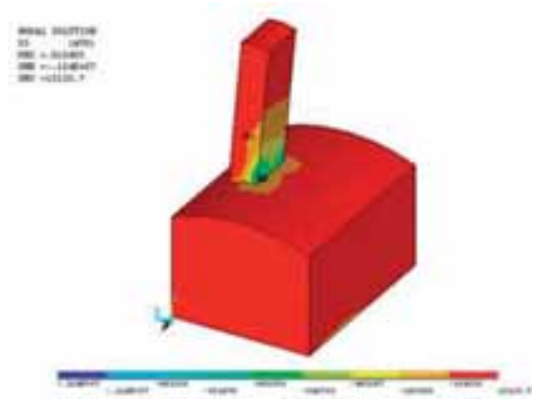

(b)

Figure 14: Induced stresses in the 6-m high wind tower due to the Northridge earthquake at the time of failure: (a) first principal stress and (b) third principal stress.

Table 4: Induced stresses in the 6-m high wind tower due to the Northridge earthquake at the time of failure.

Time of failure (s)

Maximum displacement (m)

Maximum tensile stress (MPa)

Maximum tensile stress/tensile strength (\%)

Maximum compressive stress (MPa)

Maximum compressive stress/compressive strength (\%)

Willam-Warnke criterion

\subsection{9}

0.0124

0.21

56.76

1.24

33.97

Violated

the wind tower performs as a ventilator, the cool air of the courtyard or basement is used for cooling the building. Wind direction and velocity, and height of a wind tower affect mass flow and temperature. The wind direction of $45^{\circ}$ causes more mass flow than other directions; in some case up to $43 \%$ more. A taller wind tower increases the air temperature and decreases the mass flow entering from the wind tower to the building. Air temperature increase is less than $0.5^{\circ} \mathrm{C}$. Mass flow decrease is more than $13 \%$ for increasing the wind tower height from 4 to $10 \mathrm{~m}$. A larger velocity of wind decreases the air temperature and increases the mass flow. Increasing wind velocity from 7.5 to 15 $\mathrm{m} / \mathrm{s}$ causes a $65 \%$ increase in mass flow. Wind towers are vulnerable against earthquakes. Taller wind towers experience more damage due to earthquakes than lower ones.

\section{REFERENCES}

[1] Yarshater, E., Encyclopedia Iranica, Vol. 2, Routledge \& Kogan Paul Press: New York, 1989.

[2] Masouda, S., Excavations at Tape Sang-e-Cagmag. Proceedings of the 2nd International Symposium on Archeological Research in Iran, Tehran, 1974.

[3] Hejazi, M., Historical Buildings of Iran: their Architecture and Structures, Computational Mechanics Publications (WIT Press): Southampton \& Boston, 1997.

[4] Hejazi, M. \& Mehdizadeh Saradj, F., Persian Architectural Heritage: Form, Structure and Conservation, WIT Press: Southampton \& Boston, 2013. 
[5] Hejazi, M. \& Mehdizadeh Saradj, F., Persian Architectural Heritage: Architecture, WIT Press: Southampton \& Boston, 2013.

[6] Hejazi, M. \& Mehdizadeh Saradj, F., Persian Architectural Heritage: Structure, WIT Press: Southampton \& Boston, 2013.

[7] Hejazi, M. \& Mehdizadeh Saradj, F., Persian Architectural Heritage: Conservation, WIT Press: Southampton \& Boston, 2013.

[8] Roaf, S., The Wind Catcher of Yazd, PhD Thesis, Oxford Polytechnic: Oxford, 1988.

[9] Memari,Gh., Study and Comparison of Two New Designs of Wind Towers (in Farsi), BSc Thesis, Sharif University of Technology: Tehran, 1991.

[10] Mahyari, A., The Wind Catcher, PhD Thesis, University of Sydney: Sydney, 1996.

[11] Ghiabaklou, Z., A Passive Evaporative Cooling System for Residential Buildings, PhD Thesis, New South Wales University: Kensington, 1996.

[12] Dehqani, A.R., Experimental Study of Performance of Two New Designs of Wind Towers and Comparison with Conventional Ones (in Farsi), BSc Thesis, University of Yazd: Yazd, 2001.

[13] Mousavidavar, S.S., Experimental and Analytical Study of Performance of Wind Towers and Feasibility in Cooling Systems of Buildings (in Farsi), BSc Thesis, University of Guilan: Rasht, 2002.

[14] Arjanan Mirjani, M., Wind Towers of Yazd (in Farsi), MA Thesis, University of Tehran: Tehran, 2004.

[15] Mahmoudi, M., Study of Effect of Wind Tower Properties on Thermal Behaviour (in Faris), $\mathrm{PhD}$ Thesis, Science and Research Branch, Islamic Azad University: Tehran, 2006.

[16] Bahadori, M.N. \& Yaghoubi, M., Natural Air Conditioning and Cooling in Persian Traditional Buildings (in Farsi), Markaz Nashr Daneshgahi: Tehran, 2006.

[17] Bahadori, M.N., Passive cooling systems in Iranian architecture. Scientific American, 238, pp. 144-154, 1978. doi: http://dx.doi.org/10.1038/scientificamerican0278-144

[18] Bahadori, M.N., Viability of wind towers in achieving summer comfort in the hot arid regions of the Middle East. Renewable Energy, 5(2), pp. 879-892, 1994. doi: http://dx.doi. org/10.1016/0960-1481(94)90108-2

[19] Bahadori, M.N., An improved design of wind towers for natural ventilation and passive cooling. Solar Energy, 35(2), pp. 119-129, 1985. doi: http://dx.doi.org/10.1016/0038-092X(85)90002-7

[20] Yaghoubi, M.A., Sabzevari, A. \& Golneshan, A.A., Wind towers: measurement and performance. Solar Energy, 47(2), pp. 97-106, 1991. doi: http://dx.doi.org/10.1016/0038092X(91)90040-4

[21] Badran Ali, A., Performance of cool towers under various climated in Jordan. Energy and Buildings, 35, pp. 1031-1035, 2003. doi: http://dx.doi.org/10.1016/S0378-7788(03)00067-7

[22] Nouanegue, H.F., Alandji, L.R. \& Bilgen, E., Numerical study of solar-wind tower systems for ventilation of dwellings. Renewable Energy, 33(3), pp. 434-443, 2008. doi: http://dx.doi. org/10.1016/j.renene.2007.03.001

[23] Bahadori, M.N., Mazidi, M. \& Dehghani, A.R., Experimental investigation of new designs of wind towers. Renewable Energy, 33, pp. 2273-2281, 2008. doi: http://dx.doi.org/10.1016/j. renene.2007.12.018

[24] Kalantar, V., Numerical simulation of cooling performance of wind tower (Baud-Geer) in hot and arid region. Renewable Energy, 34, pp. 246-254, 2009. doi: http://dx.doi.org/10.1016/j. renene.2008.03.007

[25] Mahmoudi, M.\& Mofidi, M., Effect of the climate on wind towers of Yazd and Bandar-i-Lengeh. Proceedings of the 3rd Conference on Optimisation of Fuel Conception, Vol. 1, Tehran, pp. 239-251, 2003. 
[26] Mahmoudi, M., Wind tower: elegancy of Yaz (in Farsi). Bagh-i-Nazar, 5, pp. 91-99, 2005.

[27] Ghaemmaghami, P.S. \& Mahmoudi, M., Wind tower as a natural cooling system in Iranian architecture. Proceedings of International Conference on Passive and Low Energy Cooling for the Built Environment, Santorini, pp. 71-76, 2005.

[28] Azami, A., Badgir in traditional Iranian architecture. Proc. of Int. Conf. On Passive and Low Energy Cooling for the Built Environment, Santorini, pp. 1021-1026, 2005.

[29] Dehnavi, M., Hossein Ghadiri, M., Mohammadi, H. \& Hossein Ghadiri, M., Study of wind catchers with square plan: influence of physical parameters. Modern Engineering Research, 2(1), pp. 559-564, 2012.

[30] Hejazi, M. \& Hejazi, B., Cooling performance of Persian wind towers. Proceedings of the 4th International Conference on Harmonisation between Architecture and Nature (EchoArchitecture 2012), Greece, pp. 197-207, 2012.

[31] Zomarshidi, H., Iranian Architecture: Building with Traditional Materials (in Farsi), Khajeh Press: Tehran, 1995.

[32] Bahadori, M.N.\& Chamberlain, M.J., Simplification of weather data to evaluate daily and monthly energy needs of residential buildings. Solar Energy, 36(6), pp. 499-507, 1986. doi: http://dx.doi.org/10.1016/0038-092X(86)90014-9

[33] Duffie, J.A. \& Beckman, W.A., Solar Engineering of Thermal Processes, Wiley, New York, 1991.

[34] Binda, L., Fontana, A. \& Frigerio, G., Mechanical behaviour of brick masonries derived from unit and mortar characteristics. Proceedings of the 8th International Brick and Block Masonry Conference, ed. J.W. de Courcy, Elsevier Applied Science: London, pp. 205-216, 1988.

[35] Korany, Y., Mechanics and modelling of URM structures. Proceedings of International Course on Architectural and Structural Design of Masonry, Dresden University of Technology, Dresden, pp. Kor-1-28, 2003.

[36] Iranian Code of Practice for Seismic Resistant Design of Buildings, Standard No. 2800-05 (in Farsi), 3rd edn., Building and Housing Research Centre: Tehran, 2005. 